\title{
Antimicrobial, Antiviral Activity and GC-MS Analysis of Essential Oil Extracted from Achillea fragrantissima Plant Growing In Sinai Peninsula, Egypt
}

\author{
Gamil S G Zeedan ${ }^{1 *}$, Abeer M. Abdalhamed ${ }^{1}$, Mahmoud E. Ottai ${ }^{2}$, Sobhy-Abdelshafy ${ }^{1}$ and Eman Abdeen ${ }^{3}$
}

${ }^{1}$ Department of Parasitology and Animal Diseases, Veterinary Research Division, National Research Centre,Dokki, Giza, Egypt ${ }^{2}$ Department of Genetics and cytology, Genetic Engineering and Biotechnology Division, National Research Centre, Dokki, Giza, Egypt ${ }^{3}$ Department of Bacteriology, Immunology and Mycology, Faculty of Veterinary Medicine, University of Sadat City, Monifia, Egypt

\begin{abstract}
Medicinal plants are considered new resources for producing agents that could act as alternatives to antibiotics in treatment of antibiotic-resistant bacteria. The present study aimed to evaluate the efficacy of essential oil extracted from Achillea fragrantissima plant growing in Egypt for antimicrobial, antiviral activities and chemical composition analyzed by Gas Chromatography-Mass Spectrometry (GC-MS). We also performed determination of essential oil antimicrobial activity by agar desk diffusion method and Minimal Inhibitory Concentration (MIC). Also, antiviral activity on ORF virus by pock reduction test was performed. It was reduced virus titer from 5.9 to 1.00 at 180 minutes. Detection of beta lactams resistant bacteria (Gram-positive bacteria Staphylococcus aureus, Staphylococcus epidermidis (MRSA) and Gram-negative bacteria Escherichia coli) by PCR with primers of mecA gene and Bela gene. The essential oil obtained by hydrodistillation was analyzed by GC-MS. The major components were found to be Santolina triene (1.97\%), 2,5,5-trimethyl-3,6-heptadien-2-ol (8.23\%) Eucalyptol 8.17, trans-2,7-Dimethyl4,6octadien-2-ol $(24.40 \%)$, 1,5-Heptadien-4-one-3,6-trimethyl (7.65\%), Artemisia alcohol (3.49\%), à Thujone $(33.97 \%)$, Cissabinol (1.92\%), Lavandulol (0.71\%), 2-Octen-4-ol, 2-methyl (2.02\%), 3-Cyclohexen1ol,4-methyl1 (1 methylethyl) (CAS) $(2.15 \%)$, à terpineol ( $0.05 \%)$, Estragole $(0.71 \%)$ Lavandulyl acetate $(0.49 \%)$, Sabinyl acetate $(2.12 \%)$, Germacrened $(0.94 \%)$. Finally, our study proved that the essential oil has bactericidal effect on some bacterial resistant antibiotic (Gram-positive bacteria Staphylococcus aureus, Staphylococcus epidermidis (MRSA) and Gram-negative bacteria Escherichia coli ) as well as antiviral activity on ORF virus but it is still need further extensive studies for safety and drug interaction.
\end{abstract}

Keywords: Achillea fragrantissima; Essential oil; Antimicrobial activity; GC/MS; Antiviral; PCR

\section{Introduction}

Medicinal plants still constitute one of the major source of drugs in modern as well as traditional medicine throughout the world [1,2]. Since a long period of time, plants have been a valuable source of natural products for maintaining animals and human health $[2,3]$. The development of multidrug-resistant(MDR) bacteria takes place because of the accumulation of different antibiotic resistance mechanisms inside the same strain which able to live in the presence of antibiotics drugs so that standard treatments become ineffective [4,14-16]. Although, the pharmacological companies have produced a number of new antibiotics recently, but even then microorganism resistance to antibiotics increased throughout the world $[5,7]$. This situation has attract attention of researchers towards herbal products for developing and improve the antibacterial drugs quality $[6,7]$.

Natural products of higher plants may possess a new source of antimicrobial agents with possibly novel mechanisms for treatment of infectious diseases [8,9]. Medicinal plants contain active principles which can be used as alternative effective herbal drugs against common bacterial infections [10]. They would be the best source to obtain a variety of drugs and active compounds. Therefore, such plants should be investigated to better understand their properties, safety and efficiency [11]. Essential oils are commercially used in different industries such as pharmaceutical, agronomic, food, sanitary, cosmetic and perfume [12]. In medicine they are used antioxidant, antitumor and antifungal [13-16].

The genera Achillea belongs to Family Asteraceae are widely distributed in the Middle East countries [17]. Ancient people had been used Achillea species in traditional medicine to alley pain, spasms and inflammation [18,3,4]. In Arabian countries all Achillea species were referred to locally names as Qaysum, Gesoom or Bu'eithraan [20,42] Numerous studies describe the various pharmacological effects of the Achillea fragrantissima hydrodistilled volatile oils in management of several diseases, used topically and orally [18-21].

Researchers studied antibacterial properties of various plants against Gram-negative as well as Gram-positive bacterial strains but only few reports on drug resistant bacteria and antiviral activity. Our study was aimed to evaluate in vitro antibacterial of essential oil extracted from Achillea fragrantissima plant against Gram-positive bacteria Staphylococcus aureus, Staphylococcus epidermidis (MRSA) and Gram-negative bacteria Escherichia coli isolated from bovine mastitis as well as antiviral activity against ORF virus isolated from skin lesion of human and animals.

\footnotetext{
*Corresponding author: Gamil S G Zeedan, Department of Parasitology and Animal Diseases, Veterinary Research Division, National Research Centre, P.O. Box 12622 El-Behouse Street, Dokki, Giza, Egypt, Tel.: +20233371499; Fax: +20233370931; Mobile: 01114513605; E-mail: gamilzee@yahoo.com

Received September 20, 2014; Accepted October 07, 2014; Published October 14,2014

Citation: Zeedan GSG, Abdalhamed AM, Ottai ME, Abdelshafy S, Abdeen E (2014) Antimicrobial, Antiviral Activity and GC-MS Analysis of Essential Oil Extracted from Achillea fragrantissima Plant Growing In Sinai Peninsula, Egypt. J Microb Biochem Technol S8: 006. doi:10.4172/1948-5948.S8-006

Copyright: (c) 2014 Zeedan GSG, et al. This is an open-access article distributed under the terms of the Creative Commons Attribution License, which permits unrestricted use, distribution, and reproduction in any medium, provided the original author and source are credited
} 
Citation: Zeedan GSG, Abdalhamed AM, Ottai ME, Abdelshafy S, Abdeen E (2014) Antimicrobial, Antiviral Activity and GC-MS Analysis of Essential Oil Extracted from Achillea fragrantissima Plant Growing In Sinai Peninsula, Egypt. J Microb Biochem Technol S8: 006. doi:10.4172/19485948.S8-006

Page 2 of 7

\section{Materials and Methods}

\section{Plant material and extraction}

The aerial parts with leaves and flowers of Achillea fragrantissima plant were collected from Saint Catherine, South Sinai, Egypt in November 2013. Authentication of the plant was performed by the group of Genetics and Breeding of Medicinal and Aromatic plants at the Department of Genetics and cytology, Genetic Engineering and Biotechnology Division, National Research Centre, Cairo, Egypt. These samples were air-dried in shade at room temperature until constant weight (about 20 days). The dried aerial parts of the plant materials were grounded with a blender. The aerial plant parts powder was stored at $4^{\circ} \mathrm{C}$ in a tightly covered bottle. One hundred grams of plant powder was subjected to hydrodistillation in a microscale $(\mathrm{v} / \mathrm{w})$ return flow distillation apparatus according to [25]. The essential oil was collected, dried over anhydrous sodium sulphate and stored at $4^{\circ} \mathrm{C}$ until used.

\section{Gas chromatography and mass spectrometry (GC-MS)} analysis

The essential oil was analyzed by Gas Chromatography-Mass Spectrometry (GC-MS) (NRC-GC/El-MS Lab), according to method [25-27] column with $0.25 \mu \mathrm{m}$ film thickness, Helium was used as carrier gas; the flow through the column was $1.4 \mathrm{ml} / \mathrm{min}$. The column temperature was programmed from 40 to $85^{\circ} \mathrm{C}$ at $20^{\circ} \mathrm{C} / \mathrm{min}$, increased from 85 to $300^{\circ} \mathrm{C}$ at rate of $5^{\circ} \mathrm{C} / \mathrm{min}$ and finally held for $10 \mathrm{~min}$. The MS operating parameters were as follows: ionization potential, $70 \mathrm{~V}$; ionization current, $2 \mathrm{~A}$; ion source temperature, $200^{\circ} \mathrm{C}$, resolution, 1000. Mass unit were monitored from 30 to $450 \mathrm{~m} / \mathrm{z}$. Determination and identification of each components in the oil was based on RI relatives to $\mathrm{n}$-alkanes and computer matching with library search report, as well as by comparison of the fragmentation patterns of mass spectra [27].

\section{Bacterial strain}

Microbial strains: Gram-positive bacteria Staphylococcus aureus, Staphylococcus epidermidis (MRSA) and Gram-negative bacteria Escherichia coli were isolated from bovine mastitis provided by Veterinary Research Division at National Research Center (NRC), Egypt. All bacteria strains were stored in broth containing 25\% (v/v) glycerol (Sigma- Aldrich) at $-20^{\circ} \mathrm{C}$. Prior to use, the culture were propagated twice in the appropriate media with shaking for $24 \mathrm{~h}$ at $37^{\circ} \mathrm{C}$ to physiologically active them.

\section{Virus strain}

The egg-adapted ORF virus was provided by Dr. G.S. Zeedan, NRC, Cairo, Egypt. Virus was propagated in the Chorio-Allantoic Membranes (CAM) of Specific Pathogen Free (SPF) embryonated chicken eggs (11 days age) as previously described by [28]. Both CAM and AF were harvested and ground in $0.1 \mathrm{M}$ sterile PBS. The homogenate was frozen at $-20^{\circ} \mathrm{C}$ and thawed three times and then centrifuged at $3000 \mathrm{rpm} / 15$ min. Then supernatant was titrated and stored at $-20^{\circ} \mathrm{C}$ until used.

\section{Animal used}

Twenty five clinically healthy Albino rats (130-150 g body weight) were obtained from Animal house of National Research Center Cairo Egypt, and randomly divided into 5 groups for experiment. The Animals were housed in a well-ventilated animal room under standardized conditions of $24^{\circ} \mathrm{C}$; relative humidity $50 \pm 5 \%$ and 12 hours light/dark cycle at the Animal House, National Research Center, Giza, Egypt. Feed and water were supplied adlibitum to meet the requirements of the NRC [29]. Rats were acclimatized for 15 days before the start of the experiment.

\section{Toxicity of essential oil}

Essential oil was diluted as the following: 100, 200, 300, 400 and $800 \mu \mathrm{l} / \mathrm{ml}$ then $1 \mathrm{ml}$ for each rat was injected S.C/I.P twice dose one week interval. Behavioral alterations, inflammatory effects, illness, and weight changes were recorded for 2 weeks post-treatment. Control animals (Rats). The toxicity of essential oil in ECE was examined as follows: inculcated $0.2 \mathrm{ml}$ from each concentration of essential oil into Chorio-Allantoic Membranes (CAM) and Chorio-Allantoic Sac (CAS) incubated at $37^{\circ} \mathrm{C}$ for 7 days daily examination. The maximum nonlethal dose was taken as the maximum non-toxic concentration.

\section{Antiviral activity of essential oil determined by Pock Reduction Assay}

Virus titers were estimated from cytopathogenicity by tenfold dilution method $0.02 \mathrm{ml}$ of each dilution was inoculated in five CAM of ECE for each dilution and expressed as 50 \% Egg Infectious Dose per $\mathrm{ml}($ EID $50 / \mathrm{ml})$. The calculation Calculated for each tested were was performed according to [30].

\section{Antimicrobial activity}

Essential oils were individually tested against Gram-positive bacteria Staphylococcus aureus, Staphylococcus epidermidis (MRSA) and Gram-negative bacteria Escherichia coli were previously isolated from bovine mastitis by Agar diffusion methods and Minimal Inhibitory Concentration (MIC).

Agar diffusion method: These methods were performed according to Forbes et al. [31]. Bacteria cultures were diluted with sterile physiological saline solution with reference to the MC Farland 0.5 standard to achieve inoculums of approximately $10^{6} \mathrm{CFU} / \mathrm{ml}$. A suspension was swab in three directions on $4 \mathrm{~mm}$ thick Mueller Hinton Agar (MHA) (Oxoid) with a cotton swap. Modified discs of $6 \mathrm{~mm}$ were prepared using a Whitman filter paper. 100 discs were obtained by punching and putting in vials-bottles and sterilizing in an oven at $170^{\circ} \mathrm{C}$ for $30 \mathrm{~min}$. The discs were impregnating with $20 \mu \mathrm{l}$ of essential oil. Prepared discs containing the various essential oil were carefully placed on the inoculated plates using a sterilized forceps in each case [31]. The disc with solvent alone used as negative control and antibiotic discs as control positive. The plates were then turned upside-down and incubated at $37^{\circ} \mathrm{C}$ for $24 \mathrm{~h}$ in an incubator by the same manner used rosette with 6 well puncture the agar and $50 \mu \mathrm{l}$ each well by essential oil, Tween 20 with saline and saline only as control negative. The results were taken by measuring the Diameter of the Inhibition Zone (DIZ) around the disc or well. This was repeated thrice and mean \pm SD was calculated.

\section{Minimal inhibitory concentration (MIC) using microdilution method}

It was done according to [32,33] guidelines for determination of Minimum Inhibitory Concentration (MIC). The MIC was defined as lowest concentration of essential oils that inhibiting visible bacterial growth after incubation for $20 \mathrm{~h}$ at $37^{\circ} \mathrm{C}$. Into each well of microplate $100 \mu$ of Mueller-Hinton Broth (Oxoid) inoculated with the bacteria strain. An aliquot $(100 \mu \mathrm{l})$ of the essential oil was added in first well serial dilutions of the essential oils were prepared in a 96 well micro titer plate, including one growth control and one sterility control. The contents of the wells were mixed and micro plates were incubated 
Citation: Zeedan GSG, Abdalhamed AM, Ottai ME, Abdelshafy S, Abdeen E (2014) Antimicrobial, Antiviral Activity and GC-MS Analysis of Essential Oil Extracted from Achillea fragrantissima Plant Growing In Sinai Peninsula, Egypt. J Microb Biochem Technol S8: 006. doi:10.4172/19485948.S8-006

Page 3 of 7

at $37^{\circ} \mathrm{C}$ for $24 \mathrm{~h}$. Micro titer plates were incubated at $37^{\circ} \mathrm{C}$ for $24 \mathrm{~h}$. The activity was measured as a function of turbidity. Lack of turbidity was further confirmed by pouring suspension aliquot of $0.1 \mathrm{ml}$ into pre-sterilized Petri dishes with nutrient agar medium. The tests were conducted in triplicate.

\section{Estimation of the number of the viable bacterial cells}

The time that taken by essential oil to kill staphylococcus and E. coli were evaluated by the time-kill assay method. The Time-kill curves were performed in tube containing nutrient or Muller Hinton broth, using inoculums density of approximately $\left(10^{6} \mathrm{CFU} / \mathrm{mL}\right)$ in the presence of essential oil. The tubes were continuously shaken and incubated at $37^{\circ} \mathrm{C}$. Samples were obtained at $0,2,4,8$ and 16 . At each sample time, they were taken and serially diluted $\log 22,4,8,16,32$. $100 \mu \mathrm{l}$ of undiluted and diluted samples were inoculated on nutrient agar or Muller Hinton agar. The plates were incubated at $37^{\circ} \mathrm{C}$ for $24 \mathrm{~h}$ at the appropriate temperatures, the number of colonies on each plate was counted, and the number of the viable cells in the cultures was calculated.

\section{Polymerase chain reaction $(\mathrm{PCR})$}

Detection of the mec A and Bela A Genes for Staphylococcus epidermidis strains and E. coli were accomplished using PCR amplification. Cells were suspended in a lysis buffer containing $1 \mathrm{M}$ Tris $\mathrm{HCl}, 5 \mathrm{M} \mathrm{NaCl}$, and $0.1 \mathrm{M} \mathrm{EDTA}$, which was incubated at $95^{\circ} \mathrm{C}$ for 10 minutes. After incubation, the suspension was centrifugated at 23000 $\mathrm{rpm}$ for $5 \mathrm{~min}$. The supernatant was used as a template in PCR. PCR assay was carried out as described by [34]. Using primers Beta-lactams gene resistant MRSA Mec A F (GTGAAGATATACCAAGTGATT) and $\mathrm{R}$ (GTGAAGATATACCAAGTGATT) gave $147 \mathrm{bp}$ PCR product of mecA gene from strains Staphylococcus epidermidis and/also using primer Beta-lactams gene resistant for $E$. coli bla C (F) TGGCCAGAACTGACAGGCAAA (R) TTTCTCCTGAACGTGGCTGGC 462 [35,34]. The final PCR products were visualized using UV-trans-illuminator after electrophoresis on $1.5 \%$ agarose gel containing $50 \mathrm{mg} / \mathrm{mL}$ EtBr.

\section{Statistical analysis}

All data were subjected to statistical analysis including the calculation of the mean and standard Deviation. Significance between data of control and infected groups was evaluated by the Student t-test at level $\mathrm{P}<0.05$ according to [36] using SPSS for windows version 15 computer program.

\section{Results}

The volatile oil or (essential oil) was extracted from aerial parts, leaves and flowers of $A$. fragrantissima by conventional hydro distillation, which gave liquid oil, ranged pale yellow oil to yellow with a strong penetrating pleasant odor characteristic of each plant. The identified compounds, together with the Retention Indices (RI) of the compounds are shown in Table 1 . The main chemical compounds detected in the oil were Santolina triene (1.97\%), 2,5,5-trimethyl3,6-heptadien-2-ol (8.23\%) Eucalyptol 8.17, trans-2,7-Dimethyl4,6-octadien-2-ol (24.40\%), 1,5-Heptadien-4-one-3,6-trimethyl (7.65\%), Artemisia alcohol (3.49\%), à Thujone (33.97\%), Cissabinol (1.92\%),-Lavandulol (0.71\%), 2-Octen-4-ol, 2-methyl (2.02\%), 3 Cyclohexen1ol,4methyl1 (1methylethyl) (CAS) (2.15\%), à terpineol (0.05\%), Estragole $(0.71 \%)$ Lavandulyl acetate $(0.49 \%)$, Sabinyl acetate $(2.12 \%)$, Germacrened (0.94\%) as in (Table 1 and Figures 1 and 2).

\begin{tabular}{|c|c|c|c|c|}
\hline No. & RT & Compounds & RRT & Area \% \\
\hline 1 & 9.1 & Santolina triene & 0.57 & 1.97 \\
\hline 2 & 12.5 & 2,5,5trimethyl3,6he ptadien2ol & 0.75 & 8.23 \\
\hline 3 & 13.16 & Eucalyptol & 0.83 & 8.17 \\
\hline 4 & 13.67 & trans2,7Dimethyl4, 6octadien2ol & 0.86 & 24.4 \\
\hline 5 & 14.23 & 1,5Heptadien4one, 3,3,6trimethyl & 0.89 & 7.65 \\
\hline 6 & 15.18 & Artemisia alcohol & 0.95 & 3.49 \\
\hline 7 & 15.76 & àThujone & 1 & 33.97 \\
\hline 8 & 16.62 & Cissabinol & 1.04 & 1.92 \\
\hline 9 & 17.38 & - Lavandulol & 1.09 & 0.71 \\
\hline 10 & 17.47 & 2 Octen4ol, 2methyl & 1.1 & 2.02 \\
\hline 11 & 17.42 & 3Cyclohexen1ol,4methyl1(1methylethyl)( CAS) & 1.11 & 2.15 \\
\hline 12 & 18.08 & à Terpineol & 1.13 & 1.05 \\
\hline 13 & 18.24 & Estragole & 1.15 & 0.71 \\
\hline 14 & 20.77 & Lavandulyl acetate & 1.3 & 0.49 \\
\hline 15 & 20.87 & Sabinyl acetate & 1.31 & 2.12 \\
\hline 16 & 25.84 & Germacrened & 1.62 & 0.94 \\
\hline & & Total area & & 99.99 \\
\hline
\end{tabular}

RT: Retention time

RRT: Relative retention time

Table 1: Chemical composition and relative content of the essential oil extracted from $A$. fragrantissima by Gas Chromatography-Mass Spectrometry (GC/MS) .

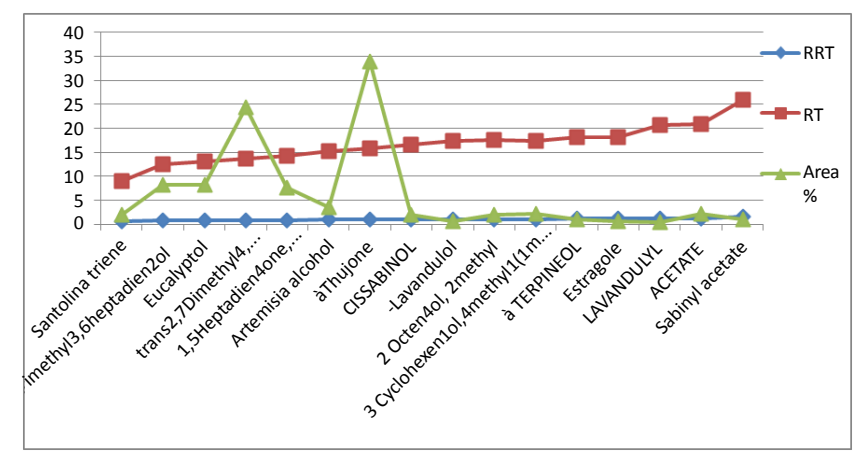

Figure 1: Determination of volatile oil fraction area by GC/MS analysis.

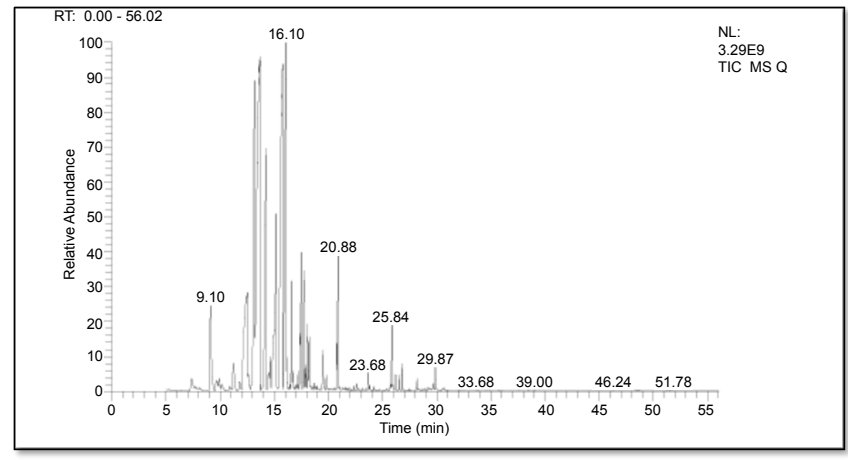

Figure 2: Achillea fragrantissima essential oil analyzed by GC-MS.

\section{Antimicrobial activity by the agar diffusion method}

The essential oil extracted from A. fragrantissima inhibited the growth of the microorganisms tested. It was especially active against Staphylococcus aureus, MRSA and E. coli. The Staphylococcus aureus showed the highest sensitivity to essential oil effect ranged from (18$22 \mathrm{~mm}-24-26 \mathrm{~mm})$ and MRSA from (14-16 mm), (16-18 mm) and followed by $E$. coli from $(8-11 \mathrm{~mm})$ and $(12-16 \mathrm{~mm})$ inhibition zone 
Citation: Zeedan GSG, Abdalhamed AM, Ottai ME, Abdelshafy S, Abdeen E (2014) Antimicrobial, Antiviral Activity and GC-MS Analysis of Essential Oil Extracted from Achillea fragrantissima Plant Growing In Sinai Peninsula, Egypt. J Microb Biochem Technol S8: 006. doi:10.4172/19485948.S8-006

Page 4 of 7

\begin{tabular}{|c|c|c|c|c|c|c|c|c|c|c|c|c|c|c|c|c|c|}
\hline \multirow[b]{2}{*}{ Microorganisms } & & \multicolumn{4}{|c|}{$\begin{array}{l}\text { Antibacterial disc diffusion } \\
\text { methods DIZ: mm }\end{array}$} & \multicolumn{4}{|c|}{$\begin{array}{l}\text { Antibacterial well diffusion } \\
\text { methods } D I Z: \mathrm{mm}\end{array}$} & \multicolumn{4}{|c|}{ MIC (mg/ml) } & \multicolumn{4}{|c|}{ MBC (mg/ml) } \\
\hline & & 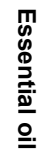 & 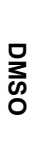 & 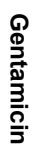 & 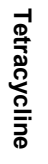 & 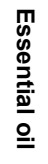 & 勇 & 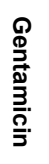 & 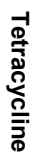 & 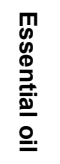 & 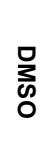 & 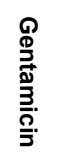 & 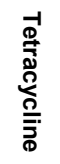 & 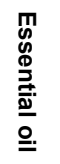 & $\begin{array}{l}\text { O } \\
\text { క్ } \\
\text { O }\end{array}$ & 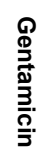 & 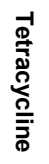 \\
\hline \multirow{3}{*}{$\begin{array}{l}\text { Gram positive } \\
\text { bacteria }\end{array}$} & S. aureus & 22 & 1 & 18 & 12 & 26 & 0 & 20 & & 6.25 & 0 & 0.01 & 12.5 & 50 & & 50 & 50 \\
\hline & S.epidermdis & 16 & 1 & $\mathrm{R}$ & $\mathrm{R}$ & 18 & 0 & $\mathrm{R}$ & $\mathrm{R}$ & 12.5 & 0 & $\geq 4$ & $\mathrm{R}$ & 25 & & $\mathrm{R}$ & $\mathrm{R}$ \\
\hline & MRSA & & & & & & & & & & & & & & & & \\
\hline $\begin{array}{l}\text { Gram negative } \\
\text { bacteria }\end{array}$ & E. coli & 11 & 0 & 20 & $\mathrm{R}$ & 12 & 0 & 22 & $\mathrm{R}$ & 0.01 & 0 & 0.01 & $\mathrm{R}$ & 0.01 & & 50 & 50 \\
\hline
\end{tabular}

Table 2: Determination of the of essential oil antibacterial activity by agar diffusion methods and Minimal Inhibitory Concentration (MIC). MIC: Minimal Inhibitory Concentration; DIZ: Diameter of Inhibition Zone: mm; MBC: Minimal Bactericidal Concentration; DMSO: Dimethylsulphoxide as negative control.

\begin{tabular}{|c|c|c|c|c|}
\hline \multirow{2}{*}{ Time } & \multirow{2}{*}{$\log _{10}$ ORFV titer kept at $37^{\circ} \mathrm{C}$} & \multirow{2}{*}{$\log _{10}$ ORFV titer kept at $4^{\circ} \mathrm{C}$} & \multicolumn{2}{|c|}{$\log _{10}$ ORFV titer was treated with essential oil (v/v). } \\
\hline & & & $\log _{10}$ titer & Reduction index \\
\hline $0 \min$ & 5.9 & \multirow{8}{*}{$5.4-5.9$} & 3.5 & 2.4 \\
\hline $15 \mathrm{~min}$ & 5.6 & & 2 & 3.6 \\
\hline $30 \mathrm{~min}$ & 5.4 & & 1.8 & 3.6 \\
\hline $45 \mathrm{~min}$ & 5.2 & & 1.6 & 3.6 \\
\hline $60 \mathrm{~min}$ & 4.8 & & 1.2 & 4.2 \\
\hline $75 \mathrm{~min}$ & 4.2 & & 0 & 4.2 \\
\hline $90 \mathrm{~min}$ & 3.9 & & 0 & 3.9 \\
\hline $105 \mathrm{~min}$ & 3.5 & & 0 & 3.5 \\
\hline
\end{tabular}

Table 3: Antiviral effect of $A$. fragrantissima essential oil on ORF virus titer by pock reduction test.

diameter by desk and well diffusion method s respectively .

\section{Discussion}

Achillea fragrantissima plant has been used for many years in traditional medicine in Middle East countries for the treatment of some diseases [37]. Several Achillea plants have been found to possess antiseptic and infection preventing properties [38,39]. They are being used as ingredients in medicinal and cosmetic preparations [40]. Recently, it was documented that the essential oil has antiinflammatory, antioxidant and anti-proliferative capacities [41]. The present study showed that the essential oil has wide varieties of volatile oil terpene hydrocarbons (aliphatic and cyclic) and their corresponding isoprenoid derivatives and analogues, mixtures of these substances, terpinen-4-01 demonstrated fraction that strongly antimicrobial effect by acting only in eukaryotic bacteria cell as in Table 1 and Figures 1 and 2 and this finding is in agreement with [42].

The essential oil extracted from $A$. fragrantissima plant inhibits growth of microorganism to various degree can determined by disc and well diffusion methods according to diameter of inhibition zone. The inhibition zone of Staphylococcus aureus from $18 \mathrm{~mm}$ to $22 \mathrm{~mm}$, followed by MRSA from 12 to 16 and followed by Gram negative bacteria Escherichia coli nearly smaller to MRSA inhibition zones, from $7.0 \mathrm{~mm}$ to $10.4 \mathrm{~mm}$ Staphylococcus aureus was the most sensitive organism to A. fragrantissima essential oil than MRSA and E. coli. However, the sensitivity of Escherichia coli not only similar to that of the MRSA but also required a higher concentration from essential oil to induce the desirable bactericidal effect as in Table 2 and Figures $3 \mathrm{~A}$ and $3 \mathrm{~B}$ this results is in agreement with [43].

Surprising results that was no difference between inhibition zones of methicillin-resistant and methicillin-susceptible strain may be due to the some component of essential oil caused bacterial cell damaged this result is in agreement with [44-46]. They found that essential oil caused gross membrane damaged and provoke whole cell lysis of eukaryotic. The mechanism of spread antibiotic resistance from food animals to humans remains controversial and resistance to the same drugs [47]. The most of the bacteria isolated from bovine mastitis showed a multidrug resistant for antibiotics due to the presences of drug resistant gene as beta lactimase which easily detected and evaluated by PCR as in Figure 4 this result is in agreement with [48]. The explanation of antibacterial activity of essential oil on bacterial cell depend on the action of terpenes fraction that involving their action by causing membrane perturbation and marked leakage of cytoplasmic material lead to induce irreversible damage to the cytoplasmic membran but fully action of terpenes still unknown and this explanation is agreement with $[48,49]$.

The mecA and Bel gene coding for methicillin resistance via penicillin binding protein 2a (PBP2a) are well established and is considered as "gold standard" for detection of methicillin resistance in comparison with phenotypic methods [46,47]. Our results revealed that the inhibitory effect of essential oils on Gram-positive bacteria Staphylococcus aureus, Staphylococcus epidermidis (MRSA) and Gram-negative bacteria Escherichia coli bacteria may be due to reduction or modified of $\beta$-lactamse (methicillin) resistance but the actual mechanism is unknown. However, is likely explained by some structural change in the resistant bacteria. Firstly, volatile oils fraction can be connected with the perturbation of cell membrane, the second mechanism may be inhibited the production of protein binding protein (PBP2) by inhibition of mecA and bel genes expression and final stage involved to subset synthesis of peptidoglycan of cell wall (transpeptidation reaction), which present outside the cell membrane this explanation is agreement with [50].

The essential oil was observed safe, no effect in the nature and color of embryo fluid comparing with control as well as experimental animals this result is in agreement with [51,52]. It was reduced infectivity titer 
Citation: Zeedan GSG, Abdalhamed AM, Ottai ME, Abdelshafy S, Abdeen E (2014) Antimicrobial, Antiviral Activity and GC-MS Analysis of Essential Oil Extracted from Achillea fragrantissima Plant Growing In Sinai Peninsula, Egypt. J Microb Biochem Technol S8: 006. doi:10.4172/19485948.S8-006

Page 5 of 7

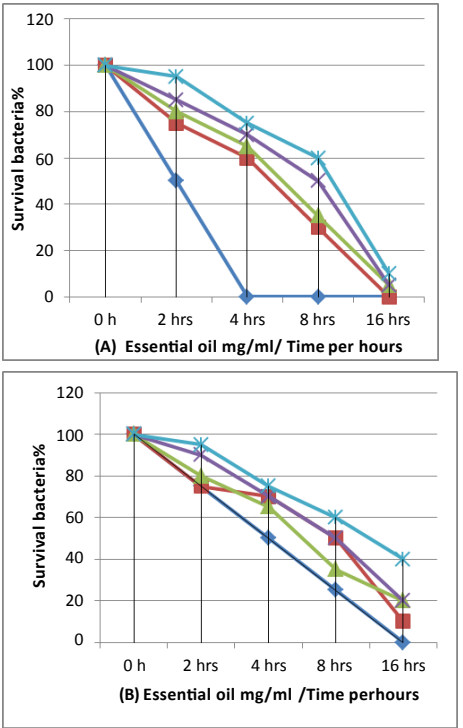

Figure 3: Effect of A Achillea fragrantissima essential oil on the viability of various microorganisms. The bacterial cells were grown broth media incubated with essential oil at $37^{\circ} \mathrm{C}$ with different time ranged from 0 to 16 hours and the number of viable cells was estimated as previously described Figure 3 (A) Staphylococcus aureus and Figure 3 (B) E. coli.

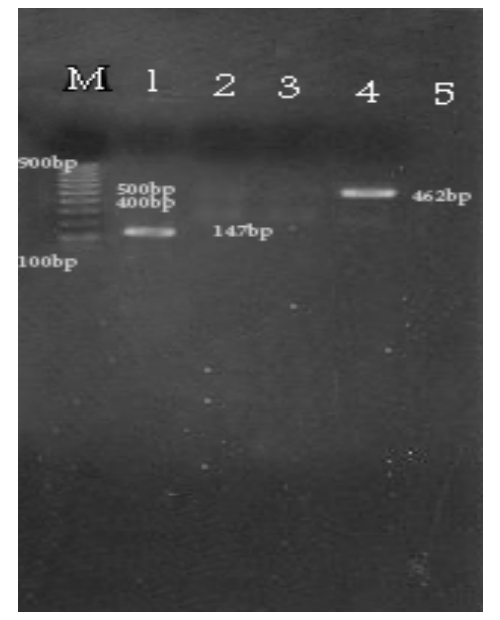

Figure 4: Electrophoretic pattern of PCR product (147 pb for mec A gene and 462 bp for bat gene ) in $1.5 \%$ agarose gel stained with ethedium bromide lane1: amplified 147 bp for MRSA mec A gene lane2, 3 and 5: negative PCR product amplified and Lane 4 amplified $462 \mathrm{bp}$ for bat gene for $E$. coli. M: DNA marker (100pb)

of ORF virus from $\log _{10} 5.9$ to 0.00 within 180 minutes. Antiviral effect of essential oil may be due to block the viral infection by blocking the cell membrane receptor for ORF virus or induce internal changes in the host cells, which in turn affect the virus replication cycle or due to production cytokines which blocked viral infection other health cells as in Table 3 and Figure 5. This result was in agreement with [53]. They found the essential oil caused sharp reduction in small pox viruses infectivity titer. Also, they observed that the concentration of viruses were reduce $\log _{10} 5-1$ and they infectivity titer were reduced 21 and 25 time more than control group. We found that the essential oil reduced plaque size and number when mixing with ORF virus before inoculation on CAM, Finally, Our results proved that the Achillea

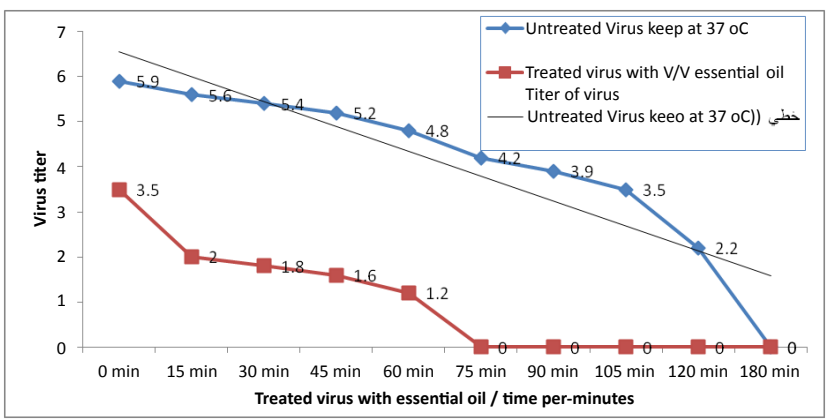

Figure 5 : Reduction of ORF virus titer by treated with $A$. fragrantissima essential oil and kept at $37^{\circ} \mathrm{C}$.

fragrantissima essential oil has antiviral and antibacterial activities on B-lactmase resistant

\section{Conclusion}

The composition of the essential oil of Achillea fragrantissima growing in Sinai, Egypt has been analyzed by GC-MS and its antimicrobial activity against Gram-positive bacteria Staphylococcus aureus, Staphylococcus epidermidis (MRSA) and Gram-negative bacteria Escherichia coli as well as antiviral activity against ORF virus reduced titer from 5.9 to 1 . Detection of B-lactam antibiotic resistance bacteria was done by PCR with primers mec A and Bela genes. The results proved that the essential oil can be used in the treatment of diseases caused by the drug resistant microorganism. But, still need further extensive researches are required to prove safety, drugs interaction and clinical studies are required to prove the safety of the oil as a medicine.

\section{Authors' Contributions}

Gamil S.G. Zeedan and Abeer M. Abdalhamed authors': conception of the research idea, study design, data collection, main part of laboratory work and interpret the data and reviewed the manuscript; Mohmoud E. Ottai and Sobhy Abdelshafy authors': study design, collection of plant from Sinai, Egypt, Identification of plant with group of Genetics and Breeding of Medicinal and Aromatic plants, data analysis of GC-MS and drafting the manuscript; Eman Abdeen author: study design and part of laboratory work. All authors have read and approved the final revised manuscript

\section{Conflict of Interests}

The authors do not have any conflict of interests regarding the content of the paper.

\section{Acknowledgement}

We would like to thank the group of Genetics and Breeding of Medicinal and Aromatic plants. Department of Genetics and cytology, Genetic Engineering and Biotechnology Division, National Research Centre, Cairo for their kind cooperation in identification of medicinal plant .

\section{References}

1. Nemeth E, Bernath J (2008) Biological activities of yarrow species (Achillea spp.). Curr Pharm Des 14: 3151-3167.

2. YeÅŸilada E, Honda G, Sezik E, Tabata M, Goto K, et al. (1993) Traditional medicine in Turkey. IV. Folk medicine in the Mediterranean subdivision. J Ethnopharmacol 39: 31-38

3. Ruth S, Aviva D, Helmut D, Günther S, Doris R, Márton K (1987) The sesquiterpene lactones from A. fragrantissima. Tetrahedron 43: 4125-4132. 
Citation: Zeedan GSG, Abdalhamed AM, Ottai ME, Abdelshafy S, Abdeen E (2014) Antimicrobial, Antiviral Activity and GC-MS Analysis of Essential Oil Extracted from Achillea fragrantissima Plant Growing In Sinai Peninsula, Egypt. J Microb Biochem Technol S8: 006. doi:10.4172/19485948.S8-006

Page 6 of 7

4. Benedek B, Kopp B (2007) Achillea millefolium L. s.I. revisited: recent findings confirm the traditional use. Wien Med Wochenschr 157: 312-314.

5. Unlü M, Daferera D, Dönmez E, Polissiou M, Tepe B, et al. (2002) Compositions and the in vitro antimicrobial activities of the essential oils of Achillea setacea and Achillea teretifolia (Compositae). J Ethnopharmacol 83: 117-121.

6. Harbottle H, Thakur S, Zhao S, White DG (2006) Genetics of antimicrobial resistance. Anim Biotechnol 17: 111-124

7. Khan R, Islam B, Akram M, Shakil S, Ahmad A, et al. (2009) Antimicrobial activity of five herbal extracts against multi drug resistant (MDR) strains of bacteria and fungus of clinical origin. Molecules 14: 586-597.

8. Bonjar S (2004) Evaluation of antibacterial properties of some medicinal plants used in Iran. J Ethnopharmacol 94: 301-305

9. Noumedem JAK, Mihasan M, Lacmata ST, Stefan M, Kuiate JR, et al. (2013) Antibacterial activities of the methanol extracts of ten Cameroonian vegetables againstGram-negativemultidrug-resistant bacteria. BMC Complementary and Alternative Medicine 13: 26-33.

10. Lentino JR, Narita M, Yu VL (2008) New antimicrobial agents as therapy for resistant gram-positive cocci. Eur J Clin Microbiol Infect Dis 27: 3-15.

11. Ali-Shtayeh MS, Yaniv Z, Mahajna J (2000) Ethnobotanical survey in the Palestinian area: a classification of the healing potential of medicinal plants. $J$ Ethnopharmacol 73: 221-232.

12. Nascimento GGF, Locatelli J, Freitas PC, Silva GL (2012) Antibacterial activity of plant extracts and phytochemicals on antibiotic-resistant bacteria. Brazilian Journal of Microbiology 31: 247-256.

13. Rajurkar NS, Gaikwad K (2012) Evaluation of photochemical, antioxidan activity and elemental content of Adiantum capillus veneris leaves. Journal of Chemical and Pharmaceutical Research 4: 365-374.

14. Sellappan S, Akoh CC (2002) Flavonoids and antioxidant capacity of Georgiagrown Vidalia onions. J Agric Food Chem 50: 5338-5342.

15. Shimada K, Fujikawa K, Yahara K, Nakamura T (1992) Antioxidative properties of xanthan on the autooxidation of soybean in cyclodextrin emulsion. Journal of Agric Food Chem 40: 945-948.

16. Skehan P, Storeng R, Scudiero D, Monks A, McMahon J, et al. (1990) New colorimetric cytotoxicity assay for anticancer-drug screening. J Natl Cancer Inst 82: $1107-1112$

17. Soltan MM, Zaki AK (2009) Antiviral screening of forty-two Egyptian medicinal plants. J Ethnopharmacol 126: 102-107.

18. Palombo EA, Semple SJ (2001) Antibacterial activity of traditional Australian medicinal plants. J Ethnopharmacol 77: 151-157.

19. Kossaibati MA, Esslemont RJ (1997) The costs of production diseases in dairy herds in England. Vet J 154: 41-51.

20. Ahmed AA, Jakupov k J, Seif El-din AA, Melek FR (1990) Irregular oxygenated monoterpenes from Achillea fragrantissima. Phytochemistry 29: 1322-1324.

21. Ahmad I, Aqil F (2007) In vitro efficacy of bioactive extracts of 15 medicinal plants against ES??L-producing multidrug-resistant enteric bacteria. Microbio Res 162: 264-275.

22. Lewis K, Ausubel FM (2006) Prospects for plant-derived antibacterials. Nat Biotechnol 24: 1504-1507.

23. Islam B, Khan SN, Haque I, Alam M, Mushfiq M, et al. (2008) Novel antiadherence activity of mulberry leaves: inhibition of Streptococcus mutans biofilm by 1-deoxynojirimycin isolated from Morus alba. J Antimicrob Chemother 62: 751-757.

24. Chovanová R, Mikulášová M, Vaverková Š ( 2013) In Vitro Antibacterial and Antibiotic resistance Modifying Effect of Bioactive Plant Extracts on MethicillinResistant Staphylococcus epidermidis. International Journal of Microbiology, Volume Article ID 760969

25. Massada Y (1976) Analysis of Essential Oil by Gas Chromatography and Spectrometry. J. Wiley \& Sons New York.

26. Adams R (1995) Identification of Essential Oil Compo- nents by Gas Chromatography/Mass Spectroscopy. Allured Publishing Co., Carol Stream, IL.

27. Vandendool H, Kratz PD (1963) A Generalization of the Retention Index System Including Linear Temperature Programmed Gas-Liquid Partition Chromatography. J Chromatogr 11: 463-471.
28. Zeedan GSG, Hassanain MA, Shaapan RM (2014) Isolation of Parapoxviruses from Skin Lesion of Man and Animals in Middle Egypt. Global Veterinaria 12 19-25.

29. Nutritional Research Council (1995) Nutrient Requirements of Laboratory Animals. Nutrient Requirements of the rat. Fourth Revised ed. National Academy Press, Washington, D.C 11-79.

30. Biacchesi S, Skiadopoulos MH, Yang L, Murphy BR, Collins PL, et al. (2005) Rapid human metapneumovirus microneutralization assay based on green fluorescent protein expression. J Virol Methods 128: 192-197.

31. Forbes BA, Sahm DF, Weissfeld AS ( 2007) Bailey and Scott's diagnostic microbiology. 12th edition. 842-55

32. Wiegand I, Hilpert K, Hancock RE (2008) Agar and broth dilution methods to determine the Minimal Inhibitory Concentration (MIC) of antimicrobial substances. Nat Protoc 3: 163-175.

33. CLSI (2011) Performance Standards for Antimicrobial Susceptibility Testing Twenty-First Informational Supplement. CLSI document M100-S21. Clinical and Laboratory Standards Institute, Wayne, $\mathrm{Pa}$, USA.

34. Zhang K, McClure JA, Elsayed S, Louie T, Conly JM (2005) Novel multiplex PCR assay for characterization and concomitant subtyping of staphylococcal cassette chromosome mec types I to $\mathrm{V}$ in methicillin-resistant Staphylococcus aureus. J Clin Microbiol 43: 5026-5033.

35. Van TT, Chin J, Chapman T, Tran LT, Coloe PJ (2008) Safety of raw mea and shellfish in Vietnam: an analysis of Escherichia coli isolations for antibiotic resistance and virulence genes. Int J Food Microbiol 124: 217-223.

36. Petrie A, Watson $P$ (1999) Statistics for Veterinary and Animal Science. 1st ed., The Blackwell Science Ltd., UK 90-99.

37. Iwu MW, Duncan ARC, Okunji O (1999) New antimicrobials of plant origin, in Perspectives on New Crops and New Uses. J Janick Edition 457-462.

38. Nitta T, Arai T, Takamatsu H (2002) Antibacterial activity of extracts prepared from tropical and subtropical plants on methicillin-resistant Staphylococcus aureus. Journal of Health Science 48: 273-276.

39. Shabana MM, Mirhom YW, Genenah AA, Aboutabl EA, Amer HA (1990) S udy into wild Egyptian plants of potential medicinal activity. Ninth communication hypoglycaemic activity of some selected plants in normal fasting and alloxanised rats. Arch Exp Veterinarmed 44: 389-394.

40. Tan HM, Cao LX, He ZF, Su GJ, Lin B. et al (2006) Isolation of endophytic actinomycetes from different cultivars of tomato and their activities agains Ralstonia solanacearum in vitro. World J Microbiol Biotechnol 22: 1275-1280.

41. Tian X, Cao L, Tan H, Han W, Chen M, et al. (2007) Diversity of cultivated and uncultivated actinobacterial endophytes in the stems and roots of rice. Microb Ecol 53: 700-707.

42. Elmann A, Mordechay S, Erlank H, Telerman A, Rindner M, et al. (2011) Anti-neuroinflammatory effects of the extract of Achillea fragrantissima. BMC Complement Altern Med 11: 98.

43. Alenad AM, Al-Jaber NA, Krishnaswamy S, Yakout SM, et al . (2013) Achillea fragrantissima extract exerts its anticancer effect via in-duction of differentiation cell cycle arrest and apoptosis in chronic myeloid leukemia (CML) cell line K562. Journal of Medicinal Plants Research 7: 1561-1567.

44. Linton AH, Howe K, Bennett PM, Richmond MH, Whiteside EJ (1977) The colonization of the human gut by antibiotic resistant Escherichia coli from chickens. J Appl Bacteriol 43: 465-469.

45. Asai T, Esaki H, Kojima A, Ishihara K, Tamura Y, et al. (2006) Antimicrobia resistance in Salmonella isolates from apparently healthy food-producing animal from 2000 to 2003: the first stage of Japanese veterinary antimicrobial resistance monitoring (JVARM). J Vet Med Sci 68: 881-884.

46. Singh S, Khatoon S, Singh H (2013) A report on pharmacognostical evaluation of four Adiantum species, Pteridophyta, for their authentication and quality control. Revista Brasileira de Farmacognosia 23

47. Kayani SA, Masood A, Achakzai AKS, Anbreen S (2007) Distribution of secondary metabolites in plants of Quetta-Balochistan. Pakistan Journal of Botany 39: 1173-1179.

48. Mustafa EH, Abu Zarga M, Abdalla S (1992) Effects of cirsiliol, a flavone isolated from Achillea fragrantissima, on rat isolated ileum. Gen Pharmacol 23 555-560. 
Citation: Zeedan GSG, Abdalhamed AM, Ottai ME, Abdelshafy S, Abdeen E (2014) Antimicrobial, Antiviral Activity and GC-MS Analysis of Essential Oil Extracted from Achillea fragrantissima Plant Growing In Sinai Peninsula, Egypt. J Microb Biochem Technol S8: 006. doi:10.4172/19485948.S8-006

49. Aboutable EA, Soliman FM, El-Zalani SM, Brunke EJ, E I-Kersh TA (1986) Essential oil of Achillea fragrantissima (Forssk.) Sch. Bip Egypt J Pharm Sci 27: $215-219$

50. Hammad HM, Albu C, Matar SA, Litescu SC, Al Jaber HI, et al. (2013) Biological activities of the hydro-alcoholic and aqueous ex-tracts of Achillea biebersteinii Afan. (Asteraceae) grown in Jordan. African Journal of Pharmacy and Pharmacology 7: 1686-1694.

51. Shahwar D, Rehman SU, Raza MA (2010) Acetyl cholinesterase inhibition potential and antioxidant activi-ties of ferulic acid isolated from Impatiens bicolor Linn. Journal of Medicinal Plant Research 4: 260-266.
52. el-Shazly AM, Hafez SS, Wink M (2004) Comparative study of the essential oils and extracts of Achillea fragrantissima (Forssk.) Sch. Bip. and Achillea santolina L. (Asteraceae) from Egypt. Pharmazie 59: 226-230.

53. Martineau F, Picard FJ, Lansac N, Ménard C, Roy PH (2000) Correlation between the resistance genotype determined by multiplex PCR assays and the antibiotic susceptibility patterns of Staphylococcus aureus and Staphylococcus epidermidis. Antimicrob Agents Chemother 44: 231-238.

54. Zmantar T, Chaieb K, Ben Abdallah F, Ben Kahla-Nakbi A, Ben Hassen A, et al. (2008) Multiplex PCR detection of the antibiotic resistance genes in Staphylococcus aureus strains isolated from auricular infections. Folia Microbiol (Praha) 53: 357-362. 